\title{
Orbital plasmasitom
}

\section{Orbital plasmasitom}

\author{
$\triangle$ Mehmet Zengin ${ }^{1}$, @Semiha Battal Havare ${ }^{2}$, @Nevra Dursun ${ }^{3}$, ๑Kadir Kotil ${ }^{4}$ \\ ${ }^{1}$ Kırıkkale Üniversitesi Patoloji Anabilim Dalı, Kırıkkale, Türkiye \\ ${ }^{2}$ İstanbul Eğitim ve Araştırma Hastanesi Patoloji Kliniği, İstanbul, Türkiye \\ ${ }^{3}$ İstanbul Eğitim ve Araștırma Hastanesi Patoloji Kliniği, İstanbul, Türkiye \\ ${ }^{4}$ İstanbul Arel Üniversitesi Sağlık Bilimleri Fakültesi, Beyin ve Sinir Cerrahisi Kliniği, İstanbul, Türkiye
}

Cite this article as / Bu makaleye atıf için: Zengin M, Battal Havare S, Dursun N, Kotil K. Orbital plasmasitom. J Med Palliat Care 2021; 2(3): 91-94.

\begin{abstract}
Öz
Ekstramedüller plazmasitom nadir görülem plazma hücreli bir neoplazidir. Sıklıkla üst solunum yollarını tutar, göz tutulumu ise son derece nadirdir. Bu bildiride orbital kaynaklı bir ekstramedüller plazmasitom olgusu sunduk. 55 yaşında erkek hasta, sol gözde şişlik nedeniyle yapılan tetkiklerinde orbital yerleşimli $5 \times 6 \mathrm{~cm}$ boyutlarında kitle tespit ediliyor. Kitlenin histopatolojik incelemesinde amiloid arasında bol miktarda plazma hücreleri izlenmiş olup kappa-lamda ile monoklonalite görülmüştür. Olgu plasma hücreli neoplazi olarak rapor edilmiş olup tetkiklerinde başka bir odak tesbit edilmediğinden soliter plasmasitom olarak kabul edilmiştir. Ekstramedüller plazmasitom orbital yerleşimli kitlelerde akılda tutulmalıdır. Prognozu farklılık gösterdiği için tanısında sistemik bir plazma hücre diskrazisinin varlığı mutlaka sorgulanmalıdir.
\end{abstract}

Anahtar kelimeler: Ekstramedüller plazmasitom, plazma hücreli neoplaziler, göz

\begin{abstract}
Extramedullary plasmacytoma is a rare plasma cell neoplasia. It often involves the upper respiratory tract, eye involvement is extremely rare. In this report, we present a case of extramedullary plasmacytoma of orbital origin. A 55-year-old male patient, an orbitally located mass with a size of $5 \times 6 \mathrm{~cm}$ was detected in the examinations performed for swelling in the left eye. In the histopathological examination of the mass, abundant plasma cells among amyloid were observed, and monoclonality with kappa-lambda was observed. The case was reported as plasma cell neoplasia and was accepted as a solitary plasmacytoma since no other focus was detected in the tests. Extramedullary plasmacytoma should be kept in mind in orbitally located masses. Since the prognosis is different, the presence of a systemic plasma cell dyscrasia should be questioned in its diagnosis.
\end{abstract}

Keywords: Extramedullary plasmacytoma, plasma cell neoplasms, eye

\section{GİRIŞ}

Ekstramedüller plazmasitom (EP) plazma hücreli neoplaziler arasında nadir görülen bir hastalıktır (1). İmmünglobulin salgılayan monoklonal hücrelerin anormal artışı ile karakterize olan plazma hücre neoplazilerinin büyük kısmını multiple myeloma (MM), kemiğin soliter plazmositomu (SP) ve EP’ler oluşturur. SP'ler, sistemik bir immünoglobülopati olan ve progresif lezyonlar olarak değerlendirilen MM'den prognoz açısından belirgin faklılık gösterirler. SP'ler klinik ve radyolojik olarak sistemik myelomatozis sergilemezler $(1,2)$. Kemiğin SP'si ve EP, plazma hücre neoplazilerinin \%5-10'unu oluşturmakta olup bu iki antite arasındaki

ayırıcı tanı lezyonun yerleşim yerlerine göre yapılır (3). EP, plevra, mediasten, tiroit, spermatik kord, over, barsak, böbrek ve deride görülse de üst solunum yolu en sik tutulan bölgedir (\%80). Üst solunum yolunda en sık görüldüğü bölgeler ise nazofarenks, nazal kavite, paranazal sinüsler ve tonsillerdir $(3,4)$. Lokalize plazma hücreli hastalıklar MM zemininde gelişebildiği gibi dissemine hastalık bulunmadan da gelişebilir (4). Burada egzoftalmus ile kliniğe başvuran, histopatolojik incelemesinde plasma hücreli neoplazi tanısı alan ve başka bir odak tespit edilmediğinden orbital plasmasitom olarak kabul edilen bir olguyu sunduk. 


\section{OLGU}

Elli beş yaşında erkek hasta, son zamanlarda artan baş ağrıları ve sol gözünde şişlik nedeniyle hastanemize başvurdu. Klinik öyküsünde 10 sene önce trafik kazası sonucu sol gözde optik sinir kompresyonu ve iki sene içerisinde progresif gelişen kızarma, morarma, şişlik ve tam görme kaybı mevcuttu. Hastanın lokal bulgular ve görme keskinliği açısından yapılan oftalmolojik muayenesinde yukarıda belirtilen bulgular teyit edildi. Yapılan göz dibi muayenesinde optik sinir başı sınırlarının belirsizliği dikkat çekiciydi ve belirgin papilödem kolaylıkla seçilebiliyordu. Görüntüleme yöntemlerinde sol göz boyunca uzanım gösterip etraf dokular ve kemik yapilarda kompresyona ve dekstrüksyona neden olan, $5 \times 6 \mathrm{~cm}$ boyutunda düzgün kontürlü kitlesel lezyon izlendi. Kitle ameliyat ile çıkarıldı. Operasyon esnasında tümörün cilt altı dokusu ve kemiğe kadar uzandığı gözlendi. Yapılan frozen incelemesinde plasma hücreli bir neoplazi düşünülerek malign olarak cevap verildi.

Histopatolojik incelemede bol amorf eozinofilik görünümdeki amiloid arasında yerleşmiş multinükleer dev hücreler ve bu hücrelerle karışık çok sayıda matür ve immatür görünümde plazma hücreleri izlenmiştir. İmmunhistokimyasal incelemede CD138 ile de plasma hücreleri boyanmış olup kongo red ve kristal viyole ile amiloid boyanmıştır (Resim 1-4). Kappa monoklonal boyanmış olup lamda ile boyanma görülmemiştir. Olgu mikroskobik ve immunhisokimyasal bulgular eşliğinde plasma hücreli neoplazi olarak rapor edilmiştir. Yapılan tetkiklerinde başka bir odak tesbit edilmediğinden SP olarak kabul edilmiștir.

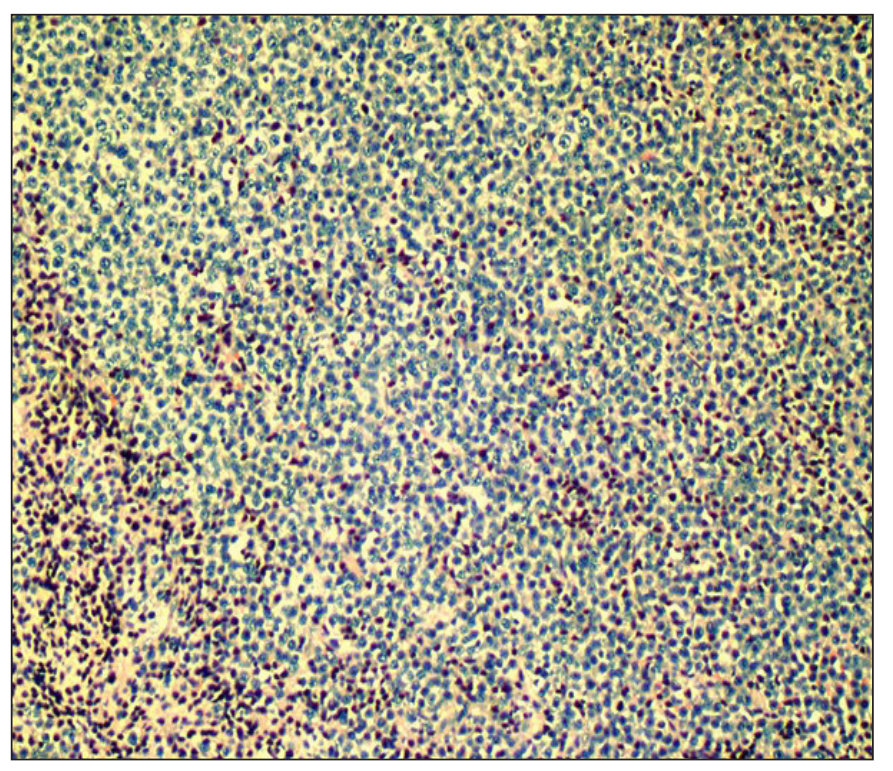

Resim 1. Plazma hücreli tümörde küçük büyütmede monoton görünümde plazma hücreleri görülmektedir $(\times 10, \mathrm{H} \& \mathrm{E})$.

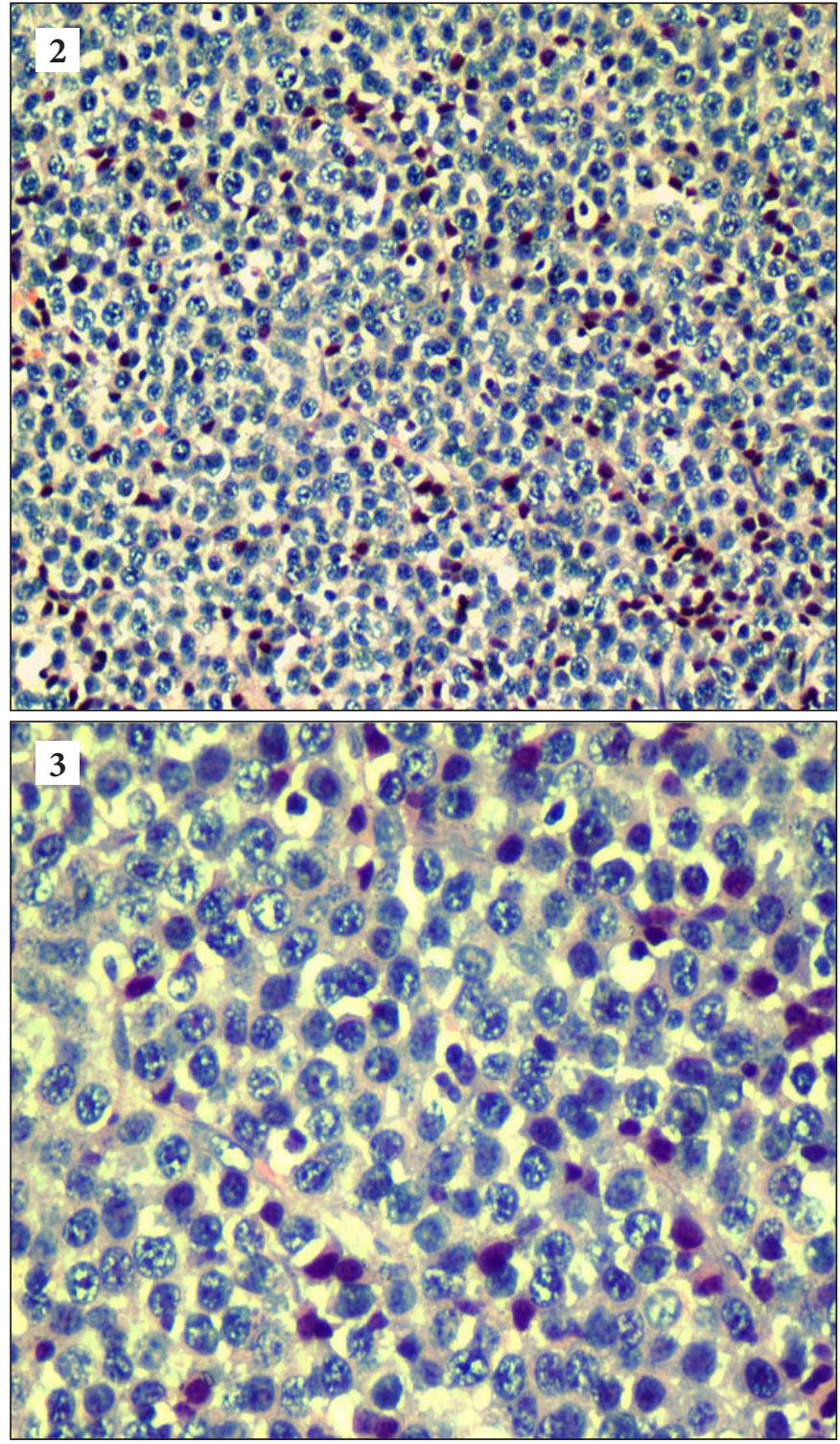

Resim 2-3. Plazma hücreli tümörde yakın büyütmede difuz matür ve immatür görünümde plazma hücreleri izlenmiştir $(\times 20-\times 40, \mathrm{H} \& \mathrm{E})$.

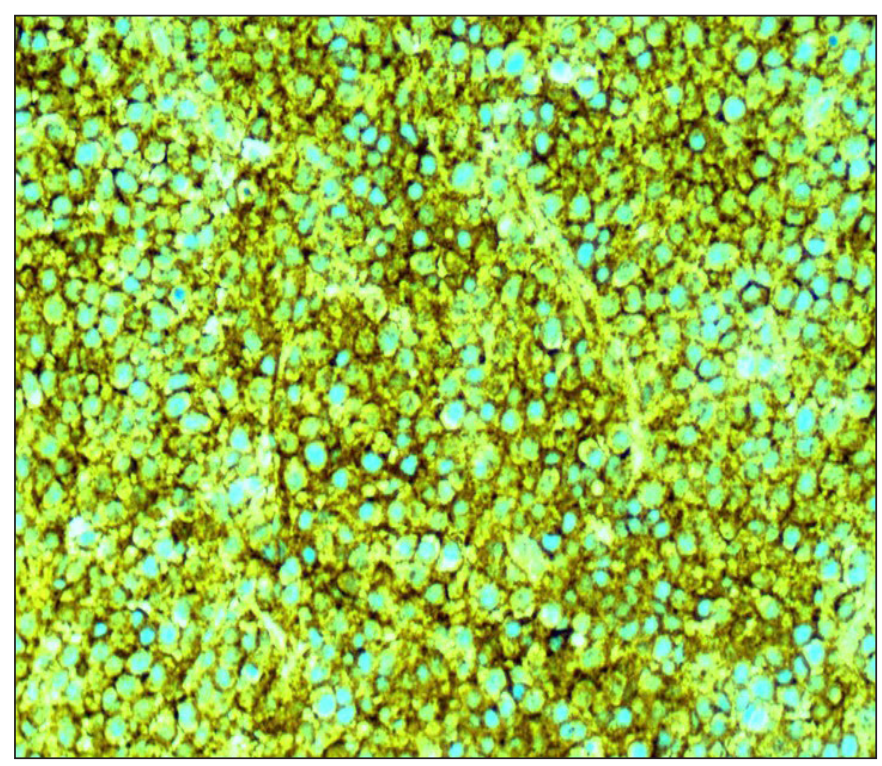

Resim 4. Plazma hücreli tümörde CD138 (+)'liği (×10, CD138) 


\section{TARTIŞMA}

Plasmositomlar erkeklerde kadınlardan 3 kat daha fazla görülür. Sıklıkla görüldüğü yaş 50-70 yaş olmakla birlikte 5 yaşında ve 89 yaşında olgular da bildirilmiştir (1). EP olgularının $\% 80$ 'i üst aerodigestif traktta lokalize olup literatürde nazal kavite, nazofarens, tonsil bölgesi, damak, diş eti, maksilla, larenks, ağız tabanı, dil ve trakea yerleşimli olgular mevcuttur $(2,3)$. Hastalığın kesin etiyolojisi belli olmamakla beraber plazma hücrelerinin proliferasyonu ve diferansiyasyonunun bazı sitokinlerle ilişkili olduğu düşünülmektedir. Bunlar arasında en önemlisi interlökin6'dır $(4,5)$. Aktif hastalığ yüksek bulunmaktadır ve bu durumun kötü prognoz ile ilişkili olduğu düşünülmektedir (5).

Primer kranyal plamasitoma olguları nadir görülür ve 2 grupta incelenebilir. Duradan kemikle ilgisi olmadan köken alan ve kemikten köken alan. Orbital plasmasitomlarda genellikle kemik tutulumu da meydana gelir (6). Seyrek olmasına rağmen literatürde orbital tutulum bildirilmiștir $(3,7,8)$. Literatürdeki bu tutulumlar rastlantısal olarak bildirilmiştir. Olgumuzdaki tutulumda rastlantısal olabileceği gibi gözdeki hasarın da bu tutulumu kolaylaştırdığını düşünmek mümkündür. Bu konu ile ilgili ileri araştırmalara ihtiyaç vardır. MM'de göz tutulumu genellikle ileri evrelerde meydana gelir. Ayrıca orbital SP'lerde uzun takipler ile sistemik gelişim tespit edilmiştir. Bu nedenle bu lezyonlarda kesin olarak EP tanısı koymak oldukça güçtür $(7,8)$.

Plasmasitoma teşhisinde kitle hemen daima mevut olan bir bulgudur ve teşhis ancak kitleden biyopsi alınıp patolojik olarak incelendiğinde konabilir. İnce iğne biyopsisi özel boyama için yeterli doku sağlamadığı için tanı koydurucu değildir $(9,10)$. Eğerkitleden biyopsi planlanacaksa mutlaka derin biyopsi alınmalıdır, çünkü lezyon submukozal yerleşimlidir ve inflamatuar reaksiyon nedeniyle kitle üzerindeki mukoza kalınlaşmış olabilir. Lezyonun histolojik görünümü kapiller stroma içine yerleşmiş plazma hücrelerinden oluşur (10,11). EP olgularının takibinde yaklaşı $\% 48$ oranında primer bölgeden yayılım veya lenf noduna yayılım saptanmıştır. Ancak lenf nodu tutulumu prognozu kötü etkilememektedir $(12,15)$.

EP hastalığın yaygınlığına göre 3 evreye ayrilır. Evre-I, hastalık sadece bir bölgededir. Evre-II, hastalıkta lokal lenf nodu tutulumu vardır. Evre-III, hastalıkta metastatik yayılım vardır (12-15). EP için önemli olan tek bir bölgeye lokalize hastalık bulunduğunda bunun sistemik bir plazma hücre diskrazisinin komponenti olup olmadığının ayırdedilmesidir. EP ve kemiğin SP'si, MM'ye göre daha iyi prognoza sahiptir. Ayrıca EP, kemiğin SP’ye göre daha iyi prognoza sahip olup 10 ylllı yaşam EP'de \%70 iken kemiğin SP'sinde \%16'dır $(14,15)$. Bu iki antitenin MM'den ayırt edilmesinde a-kemik iliğinde plazmositozis olmaması, b-kemik ağrısı, anemi, böbrek yetmezliği gibi klinik bulguların olmaması, c-serum veya idrarda monoklonal gammopati olmaması ve d-direkt grafide osteolitik lezyon olmaması gereklidir (15).

MM, EP ve SP devam eden sistemik bir hastalığın farklı görünümleri olarak ortaya çıkabilir ve izole vakalarda tedavi ve prognoz yönünden birbirlerinden ayırdedilmeleri son derece önemlidir (13-15). Bu nedenle potansiyel malignite riski taşıdığından bir kere plazmasitom tanısı konduğunda yakın takip gerekmektedir. Gelişmiş tüm laboratuvar ve radyolojik tanı yöntemlerine rağmen EP'nin MM'ye ilerleyip ilerlemeyeceğini bilmek mümkün değildir. Ayrıca plasmasitoma tanısı konan hastaların uzun süreli takiplerinde dissemine forma dönüşmeler tespit edilmiştir $(14,15)$.

Ekstramedüller plazmositom için tedavi protokolü kliniğine ve lezyonun yerleşimine göre planlanmalıdır. Genellikle önerilmekle birlikte tek başına cerrahi tartışmalıdır ve radyoterapi mutlaka eklenmelidir (14, 15). Çünkü plazma hücreli neoplaziler yüksek oranda radyosensitiftir. Ancak radyoterapinin uzun dönem sekelleri gözönüne alındığında EP tedavisinde cerrahinin ilk basamak tedavi olarak değerlendirilmesi daha uygun olabilir (15). Lokal cerrahiyi takiben kemoterapi de önerilen tedaviler arasındadır. Plasmasitomalarda ortalama yaşam süresi yaklaşık 8 yıldır olmasına karşın MM'lerd 20 ay kadardır (15).

\section{SONUÇ}

Orbital plasmasitoma oldukça nadir görülen plazma hücreli bir neoplazidir. Lokalize formalarda prognoz genellikle iyi olmakla beraber malignleşme patonsiyeli taşıyan neoplazilerdir. Bu nedenle hastaları uzun süreli takip etmek, rekürrens ve progresyonlarda ise derhal tedaviye almak gerekmektedir.

\section{ETİK BEYANLAR}

Aydınlatılmış Onam: Bu çalışmaya katılan hasta(lar) dan yazılı onam alınmıştır.

Hakem Değerlendirme Süreci: Harici çift kör hakem değerlendirmesi.

Çıkar Çatışması Durumu: Yazarlar bu çalışmada herhangi bir çıkara dayalı ilişki olmadığını beyan etmişlerdir.

Finansal Destek: Yazarlar bu çalışmada finansal destek almadıklarını beyan etmişlerdir.

Yazar Katkıları: Yazarların tümü; makalenin tasarımına, yürütülmesine, analizine katıldığını ve son sürümünü onayladıklarını beyan etmişlerdir. 


\section{KAYNAKLAR}

1. Siegel R, Naishadham D, Jemal A. Cancer statistics. CA Cancer J Clin. 2012 2012; 62: 10-29

2. Matos A, Goulart A, Ribeiro A, et al. Orbital plasmacytoma, an uncommon presentation of advanced multiple myeloma. Eur J Case Rep Intern Med 2020; 7: 001149.

3. Wang SSY, Lee MB, George A, et al. Five cases of orbital extramedullary plasmacytoma: diagnosis and management of an aggressive malignancy. Orbit 2019; 38: 218-25.

4. Bhadauria BM, Ranjan P, Mishra D. Primary orbital plasmacytoma mimicking lacrimal gland tumor. Orbit 2014; 33: 305-7

5. Barmas-Alamdari D, Sodhi GS, Shenouda TA. Bilateral proptosis in a case of recurring multiple myeloma: uncommon orbital presentation of plasmacytoma. Int Med Case Rep J 2020; 13: 297 301.

6. Sharma S, Kaur R, Bal A, Mohindra S, et al. Primary orbital plasmacytoma: An unusual presentation in an adolescent. Indian J Pathol Microbiol 2018; 61: 158-9.

7. Vatansever M, Bozkurt FM, Dinc E, et al. Orbital metastasis of multiple myeloma: case report. Turk J Ophthalmol 2016; 46: 14850 .

8. Bhadauria M, Ranjan P, Mishra D. Primary orbital plasmacytoma mimicking lacrimal gland tumor. Orbit 2014; 33: 305-7.

9. Rodriguez T, Bon V. Secondary extramedullary bilateral orbital plasmacytoma in a 65-year-old man. J Fr Ophtalmol 2019; 42: 267-9.

10.Hsu VJ, Agarwal MR, Chen CS, et al. IgA orbital plasmacytoma in multiple myeloma. Ophthalmic Plast Reconstr Surg 2010; 26: 126-7.

11. Pierre-Filho, Paulo de Tarso P, do Carmo Carvalho F, et al. Orbital extramedullary plasmacytoma leading to exenteration. Can J Ophthalmol 2004; 39: 557.

12. Ockrim ZK, Deutch J, Izon J. Bilateral retro-orbital plasmacytoma. Eye (Lond) 2000; 14: 795-7.

13. Uceda-Montañés A, Blanco G, Saornil MA, et al. Extramedullary plasmacytoma of the orbit. Acta Ophthalmol Scand 2000; 78: 6013.

14.Liao J, Greenberg A, Shinder R. Relapsed multiple myeloma presenting as an orbital plasmacytoma. Ophthalmic Plast Reconstr Surg 2011; 27: 461.

15. Palumbo A, Rajkumar SV, Jesus F, et al. International myeloma working group consensus statement for the management, treatment, and supportive care of patients with myeloma not eligible for standard autologous stem-cell transplantation. J Clin Oncol 2014; 32: 587-600 